\title{
Survey Analisis Tingkat Kebugaran Jasmani Pelajar SMP di Pondok Pesantren Ta'dib Asyakirin Medan
}

\author{
Sabaruddin Yunis Bangun ${ }^{1}$, Johan Syahputra Zaluku ${ }^{2}$ \\ ${ }^{1,2}$ Universitas Negeri Medan, Medan, Indonesia \\ 1,2 unisbgn@unimed.ac.id
}

\begin{abstract}
ABSTRAK
Penelitian ini bertujuan untuk mengetahui tingkat kebugaran jasmani siswa SMP di Pondok Pesantren Ta'dib Asyakirin Medan. Penelitian ini merupakan penelitian deskriptif kuantitatif. Teknik pengumpulan data yang digunakan adalah tes dan pengukuran. Populasi dalam penelitian ini adalah seluruh siswa SMP yang berada di Pondok Pesantren Ta'dib Asyakirin Medan dengan jumlah 77 orang. Sampel dalam penelitian ini adalah adalah siswa SMP yang berada di Pondok Pesantren Ta'dib Asyakirin Medan dengan jumlah 77 orang. Instrumen yang digunakan dalam penelitian ini adalah dengan cara Tes Kebugaran Jasmani Indonesia (Tes TKJI). Data hasil penelitian yang telah diklasifikasi menunjukkan tingkat kebugaran jasmani siswa yang berada pada klasifikasi sedang yaitu sejumlah $9(11,69 \%)$ orang, klasifikasi kurang sejumlah 58 (75,33\%) orang, $10(12,99 \%)$ orang berada di kategori kurang sekali, dan 0 siswa $(0 \%)$ klasifikasi baik maupun baik sekali. Dapat disimpulkan bahwa tingkat kebugaran jasmani siswa SMP yang berada di Pondok Pesantren Ta'dib Asyakirin Medan berada pada kategori kurang.
\end{abstract}

Kata kunci: Kebugaran Jasmani, Pesantren Ta'dib Asyakirin

\begin{abstract}
This study aims to determine the level of physical fitness of junior high school students at the Asyakirin Ta'dib Islamic Boarding School in Medan. This research is quantitative descriptive. Data collection techniques used were tests and measurements. The population in this study were all junior high school students in the Asyakirin Islamic Boarding School in Medan with a total of 77 people. The sample in this study were junior high school students in the Asyakirin Islamic Boarding School in Medan with a total of 77 people. The instrument used in this study was the Indonesian Physical Fitness Test (TKJI Test). Research data that has been classified shows the level of physical fitness of students who are in the medium classification of 9 (11.69\%) people, less classification of $58(75.33 \%)$ people, 10 (12.99\%) people are in the category very little, and 0 students $(0 \%)$ classified well or very well. It can be concluded that the level of physical fitness of junior high school students in the Asyakirin Medan Islamic Boarding School in the category is lacking.
\end{abstract}

Keywords: Physical Fitness, Pesantren Ta'dib Al Syakirin

\section{PENDAHULUAN}

Olahraga merupakan proses sistematik yang berupa segala kegiatan atau usaha yang dapat mendorong mengembangkan, dan membina potensi-potensi jasmaniah dan rohaniah seseorang sebagai perorangan atau anggota masyarakat dalam bentuk permainan, perlombaan/pertandingan, dan prestasi puncak dalam pembentukan manusia indonesia seutuhnya yang berkualitas berdasarkan Pancasila. Bangun (2012) Olahraga di satu sisi adalah bentuk bermain yang terorganisir dan bersifat kompetitif. Olahraga merupakan aktivitas yang sangat penting untuk mempertahankan kebugaran seseorang Bangun (2016).
Memiliki kebugaran jasmani yang baik kita bisa menyesuaikan diri untuk melakukan aktivitas. Kebugaran jasmani setiap orang berbeda-beda. Dengan memiliki kebugaran jasmani yang baik kita dapat melakukan aktivitas tanpa harus mengalami kelelahan yang berarti. Cholik\&Maksum(2007) Kebugaran jasmani merupakan kemampuan seseorang dalam melakukan aktivas keseharian tanpa mengalami kelelahan yang berarti, dan masih mempunyai cadangan sisa tenaga untuk melakukan aktivitas yang lainnya.

Olahraga yang teratur maka dengan otomatis tingkat kebugaran jasmani seseorang juga akan baik. Aktivitas banyak juga ternyata tidak menjamin seseorang akan mempunyai badan yang bugar, butuh banyak kegiatan yang 
bersifat mengolah tubuh supaya aktivitas tersebut bermanfaat bagi tubuh. Seseorang yang memiliki kebugaran jasmani yang baik akan terhindar dari kemungkinan cedera pada saat melakukan aktivitas fisik atau olahraga yang lebih berat. Kurangnya daya tahan tubuh, kelentukan persendian, kekuatan otot, kecepatan dan kelincahan merupakan penyebab utama timbulnya cedera.

Dari observasi yang telah dilakukan oleh peneliti di Pesantren Modern Ta'dib Al Syakirin, ternyata masih terdapat kendala dalam hal kebugaran jasmani siswa. Hal ini mungkin disebabkan oleh pendidikan jasmani bukanlah merupakan mata pelajaran yang masuk ke dalam kurikulum sekolah, melainkan hanya sebagai kegiatan esktrakurikuler sekolah saja. Kita ketahui bahwa ekstrakurikuler adalah pelajaran tambahan yang sifatnya tidak diwajibkan bagi para siswa, tetapi hanya sebagai pelengkap mata pelajaran saja. Padahal pendidikan jasmani adalah satu - satunya pelajaran yang memberikan konstribusi terhadap kebugaran jasmani siswa disekolah.

Selain itu yang menjadi kendala di pesantren tersebut adalah dalam hal mengikuti pelajaran terutama pada jam pelajaran terakhir, mereka sudah terlihat lesu dan bosan, ini mengakibatan daya konsentrasi mereka menjadi menurun. Sementara para siswa setelah sepulang sekolah masih memiliki kegiatan lain seperti mengaji bersama dan kegiatan keagamaan lainnya. Selain itu ratarata setiap minggunya ada saja siswa yang tidak hadir, dikarenakan sakit.

Hasil Observasi dengan para guru di Pesantren tersebut, diketahui bahwa belum pernah diadakan tes kebugaran jasmani. Untuk mengetahui tingkat kebugaran jasmani siswa apakah memenuhi standar apa belum, maka perlu diadakan tes untuk mengetahui tingkat kebugaran jasmani siswa, yaitu dengan Tes Kebugaran Jasmani Indonesia (TKJI).

Mukholid (2004) kesegaran jasmani adalah kemampuan dan kesanggupan untuk melakukan aktivitas atau kerja, mempertinggi daya kerja dengan tanpa mengalami kelelahan yang berlebihan. Hartono, Dkk (2013), kebugaran jasmani adalah kemampuan seseorang untuk melakukan tugas, pekerjaan, atau rutinitas sehari-hari dengan fisik yang prima, tidak mengalami kelelahan yang berat setelah melaksanakan aktivitas tersebut serta memiliki kemampuan fisik yang baik untuk melakukan pekerjaan mendadak ataupun tambahan lainnya.
Harsono (2006) setiap individu memiliki tingkat kebugaran jasmani yang berbeda-beda, hal ini tergantung pada kondisi organ-organ tubuh individu tersebut. "Apabila tingkat kebugaran jasmani baik maka akan ada peningkatan dalam kekuatan, kelentukan, kecepatan, stamina dan lainnya akan ada pemulihan dalam organ-organ tubuh setelah latihan, akan ada ekonomi gerak yang lebih baik pada waktu latihan.

Lutan (2002) menyebutkan kebugaran jasmani akan mendatangkan manfaat di antaranya:

1. Terbangunnya kekuatan dan daya tahan otot seperti kekuatan tulang, persendian yang akan mendukung performa baik dalam aktivitas olahraga maupun non-olahraga.

2. Meningkatkan daya tahan aerobik.

3. Meningkatkan fleksibilitas.

4. Membakar kalori yang memungkinkan tubuh terhindar dari kegemukan.

5. Mengurangi stress

6. Meningkatkan gairah hidup Irianto(2004) komponen kebugaran jasmani yang berhubungan dengan kesehatan antara lain:

1. Daya tahan jantung dan paru adalah kemampuan paru jantung mensuplai oksigen untuk kerja otot dalam jangka waktu lama.

2. Kekuatan dan daya tahan otot. Kekuatan otot adalah kemampuan otot untuk melawan beban dalam satuan usaha. Daya tahan otot adalah kemampuan otot untuk melakukan serangkaian kerja dalam waktu lama.

3. Kelenturan adalah kemampuan persendian untuk bergerak secara leluasa.

4. Komposisi tubuh adalah perbandingan berat tubuh berupa lemak dengan berat badan lemak yang dinyatakan dengan persentase.

Kravits (2001), terdapat lima unsur komponen utama dari kebugaran yang berhubungan dengan kesehatan yang harus diperhatikan:

1. Daya tahan kardiorespirasi atau kondisi fisik aerobic adalah kemampuan jantung, paru-paru, pembuluh darah, dan grup otototot yang bisa untuk melakukan latihanlatihan yang keras dalam jangka waktu yang lama. Pemantauan kondisi aerobik yang teratur dapat mencegah penyakit jantung dan peredaran darah.

2. Kekuatan otot adalah kemampuan otot-otot untuk menggunakan maksimal atau mendekati maksimal untuk mengangkat beban. 
3. Daya tahan otot adalah kemampuan dari otot-otot kerangka badan untuk mengunakan kekuatan (tidak perlu maksimal) dalam jangka waktu tertentu.

4. Kelentukan adalah daerah gerak otot-otot dan persendian tubuh.

5. Komposisi badan adalah persentase lemak badan dari berat badan tanpa lemak (otot, tulang rawan, organ-organ vital).

Komponen kebugaran jasmani selain untuk mengetahui tingkat VO2max dibagi menjadi 2 yaitu komponen kebugaran yang berkaitan dengan kesehatan yang dirujuk untuk menjaga kesehatan dan komponen kebugaran yang berkaitan dengan keterampilan yang dirujuk untuk prestasi.Faktor-faktor yang mempengaruhi kebugaran jasmani merupakan 1) faktor umur, 2) faktor jenis kelamin, 3) faktor genetik, 4) faktor kebiasaan latihan, 5) faktor aktivitas fisik, 6) faktor kondisi kesehatan, 7) faktor pola hidup yang tidak sehat, 8) faktor kadar haemoglobin, 9) faktor istirahat dan, 10) faktor status gizi yang baik.

Survey kebugaran jasmani yang dilakukan adalah untuk melihat tingkat kebugaran jasmani pada pelajar di Pondok Pesantren Ta'dib Asyakirin. Mengetahui tingkat kebugaran jasmani pelajar, maka pendidik memiliki data untuk mencari solusi terkait kebugaran jasmani pelajar tersebut, apakah perlu dijaga atau ditingkatkan kebugaran jasmaninya. Ketika kebugaran jasmani pelajar dalam katagori baik maka berdampak positif pada pembelajaran seharihari yang dijalani pelajar-pelajar tersebut. Lebih aktif, fokus dan siap menerima pembelajaran di sekolah dalam materi apapun setiap harinya dan tanpa mengalami kelelahan yang berarti. Kebugaran jasmani pelajar sangatlah penting untuk diperhatikan dengan baik, demi terwujudnya keberhasilan pendidikan pada pelajar.

\section{METODE PENELITIAN}

Metode yang digunakan dalam penelitian ini adalah metode deskriptif dengan pendekatan kuantitatif. Pelaksanaan penelitian ini dilakukan pada tanggal Juni 2019. Lokasi Penelitian akan dilakukan di Pondok Pesantren Ta'dib Asyakirin, Jl. Brigjend Zein Hamid Km 7,5 Titi Kuning Gg. Tapian Nauli No. 5 Medan Johor.

Populasi dalam penelitian ini adalah seluruh siswa SMP yang berada di Pondok Pesantresn Ta'dib Asyakirin Medan, dan pengambilan sampel dalam penelitian ini dilakukan dengan merujuk pada, Arikunto (2006) sampel adalah sebagian atau wakil populasi yang akan diteliti. Mengenai jumlah sampel dalam penelitian ini adalah semua siswa putra dan putri tingkat SMP yang terdapat di Pesantren Modern Ta'dib Asyakirin sebanyak 77 orang.

Desain penelitian dalam penelitian ini menggunakan teknik tes dan pengukuran. Tes yang dilakukan untuk mengetahui tingkat kebugaran siswa siswi di Pondok Pesantren Ta'dib Asyakirin ini menggunakan Tes Kebugaran Jasmani Indonesia (TKJI).

Dalam penelitian ini instrumen yang digunakan adalah Tes Kebugaran Jasmani Indonesia (TKJI) untuk remaja umur $13-15$ tahun. Dimana dalam Tes Kebugaran Jasmani, Kemendiknas (2010) terdiri dari beberapa butir tes yang meliputi Lari cepat (50 meter), Gantung angkat tubuh (Pull up - 60 detik), Baring duduk (Sit up - /60 (pa) dan 30 detik (pi), Loncat tegak (Vertical Jump), dan Lari jauh (1000 meter/pa dan 800 meter/pi).

Teknik pengumpulan data dalam penelitian ini, digunakan dengan acuan tabel Nilai Tes Kesegaran Jasmani Indonesia (TKJI). Adapun tabel nilai tes kebugaran jasmani usia 13 - 15 tahun adalah:

Tabel 1. Nilai TKJI Untuk Remaja Umur 13 - 15 Tahun Putra, Kemendiknas (2010)

\begin{tabular}{|c|c|c|c|c|c|c|}
\hline & Lari 60 Meter & $\begin{array}{c}\text { Gantung } \\
\text { Angkat } \\
\text { Tubuh }\end{array}$ & $\begin{array}{c}\text { Baring } \\
\text { Duduk 60 } \\
\text { Detik }\end{array}$ & $\begin{array}{c}\text { Loncat } \\
\text { Tegak }\end{array}$ & $\begin{array}{l}\text { Lari } 1000 \\
\text { Meter }\end{array}$ & Nilai \\
\hline $\mathrm{S}$ & $\mathrm{Sd}-6,7^{\prime}$ & 16 keatas & 38 keatas & 66 keatas & Sd - 3'04" & 5 \\
\hline $\mathrm{K}$ & $6,8 "-7,6 ”$ & $11-15$ & $28-37$ & $53-63$ & 3'05" -3,53” & 4 \\
\hline A & $7,7 "-8,7 ”$ & $6-10$ & $19-27$ & $42-52$ & $3^{\prime} 54^{\prime \prime}-4^{\prime} 46^{\prime \prime}$ & 3 \\
\hline $\mathrm{L}$ & $8,8^{\prime \prime}-10.3 "$ & $2-5$ & $8-18$ & $31-41$ & 4'47" - 6’04"' & 2 \\
\hline A & $10,4 "$ - dst & $0-1$ & $0-7$ & $\mathrm{Sd} 30$ & 6 '05"dst & 1 \\
\hline
\end{tabular}


Tabel 2. Nilai TKJI Untuk Remaja Umur 13 - 15 Tahun Putri, Kemendiknas (2010)

\begin{tabular}{|c|c|c|c|c|c|c|}
\hline & Lari 60 Meter & $\begin{array}{c}\text { Gantung } \\
\text { Angkat } \\
\text { Tubuh }\end{array}$ & $\begin{array}{c}\text { Baring } \\
\text { Duduk } 60 \\
\text { Detik }\end{array}$ & $\begin{array}{c}\text { Loncat } \\
\text { Tegak }\end{array}$ & $\begin{array}{c}\text { Lari } 1000 \\
\text { Meter }\end{array}$ & Nilai \\
\hline $\mathrm{S}$ & $\mathrm{Sd}-7.7^{\prime \prime}$ & 41 keatas & 28 keatas & 50 keatas & $\mathrm{Sd}-3^{\prime} 06^{\prime \prime}$ & 5 \\
\hline $\mathrm{K}$ & $7.8^{\prime \prime}-8.7 ”$ & $22 "-40 "$ & $19-27$ & $39-49$ & $3^{\prime} 07^{\prime \prime}-3,55^{\prime \prime}$ & 4 \\
\hline A & $8.8 "-9.9 "$ & $10 "-2 ”$ & $9-18$ & $30-38$ & $3{ }^{\prime} 56^{\prime \prime}-4^{\prime} 58^{\prime \prime}$ & 3 \\
\hline $\mathrm{L}$ & $10.0 "-11.9 "$ & $3 "-9 "$ & $3-8$ & $21-29$ & 4'59" - 6'40" & 2 \\
\hline A & $12.0 "$ - dst & $0 "-2 "$ & $0-2$ & $20 \mathrm{dst}$ & 6'41'dst & 1 \\
\hline
\end{tabular}

Setelah diketahui nilai dari masingmasing butir tes tersebut, kemudian dari masing-masing nilai tes tersebut dijumlahkan dan hasil dari penjumlahan nilai-nilai tersebut dijadikan dasar untuk menentukan atau menetapkan kategori tingkat kebugaran jasmani siswa dengan memasukkan ke dalam tabel standar norma Tes Kesegaran Jasmani Indonesia, maka dengan demikian akan diketahui keadaan kebugaran jasmani siswa tersebut. Adapun standar norma Tes Kesegaran Jasmani Indonesia tersaji dalam tabel di bawah ini:

Tabel 3. Norma TKJI Untuk Remaja Umur 13 - 15 Tahun Putra dan Putri

\begin{tabular}{cclc}
\hline No & Jumlah Nilai & \multicolumn{2}{c}{ Klasifikasi } \\
\hline 1 & $22-25$ & Baik Sekali & (BS) \\
2 & $18-21$ & Baik & (B) \\
3 & $14-17$ & Sedang & (S) \\
4 & $10-13$ & Kurang & (K) \\
5 & $5-9$ & Kurang Sekali & (KS) \\
\hline
\end{tabular}

Analisis data dalam penelitian ini dimulai dari data yang terkumpul dari menjumlahkan butir tes kemudian dikonversikan ke dalam tabel kategori tes kesegaran jasmani indonesia usia 13 - 15 tahun. Kemudian dianalisis menggunakan analisis statistik deskriptif dan persentase dengan rumus:

$$
\mathrm{P}=\underline{F} \times 100 \%
$$

\section{$\mathrm{N}$}

Keterangan:

$$
\begin{aligned}
& \mathrm{P}=\text { Persentase yang diperoleh } \\
& \mathrm{F}=\text { Frekuensi } / \text { data mentah siswa } \\
& \mathrm{N}=\text { Jumlah sampel } \\
& 100 \% \text { = Nilai tetap }
\end{aligned}
$$

Analisis terhadap data setelah diperoleh persentasenya, maka untuk menemukan norma pengklasifikasian persentase yaitu sebagai berikut:

1. $80 \%-100 \%=$ Baik Sekali

2. $60 \%-79 \%=$ Baik

3. $30 \%-59 \%=$ Sedang

4. $10 \%-29 \%=$ Kurang

Kurang dari $10 \%=$ Kurang Sekali

\section{HASIL \& PEMBAHASAN}

Berdasarkan tes dan pengukuran terhadap sampel dengan menggunakan Tes Kebugaran Jasmani Indonesia untuk Remaja umur 13 - 15 tahun yang dilakukan di Pondok Pesantren Ta'dib Asyakirin. Untuk komponen lari 60 meter putra diperoleh nilai maksimum 6,3 detik dan nilai minimum 10,7 detik dengan rata - rata 7,93 detik, sedangkan untuk putri diperoleh nilai maksimum 7,7 detik dan nilai minimum 11,2 detik dengan rata rata 9,33 detik. Untuk tes angkat tubuh putra diperoleh nilai maksimum 12 kali, nilai minimum 5 kali dengan rata - rata 7 , 49 kali, sedangkan untuk tes siku tekuk putri diperoleh nilai maksimum 4 detik dan nilai minimum 1 detik dengn rata - rata 2,55 detik. Untuk hasil tes baring duduk 60 detik (putra) diperoleh nilai maksimum 27 kali, nilai minimum, 15 kali dengan nilai rata - rata 22,04 kali, sedangkan tes baring duduk 30 (putri) diperoleh nilai maksimum 23 kali dan nilai minimum 6 kali dengan rata - rata 12 kali . Untuk hasil tes loncat tegak (putra) diperoleh nilai maksimum $45 \mathrm{~cm}$ dan nilai minimum 22 $\mathrm{cm}$, dengan nilai rata - rata $32,68 \mathrm{~cm}$, sedangkan untuk hasil tes loncat tegak 
(putri) diperoleh nilai maksimum $29 \mathrm{~cm}$ dan nilai minimum $19 \mathrm{~cm}$ dengan nilai rata - rata 23,35 cm. Untuk tes lari $1000 \mathrm{~m}$ putra diperoleh nilai maksimum 4 menit 2 detik dan nilai minimum 7 menit 20 detik dengan nilai rata - rata 6 menit 10 detik, sedangkan untuk tes lari $800 \mathrm{~m}$ putri diperoleh nilai maksimum 4 menit 3 detik dan nilai minimum 7 menit 2 detik dengan nilai rata - rata 6 menit 42 detik.

Untuk lebih jelas mengenai data hasil tes tingkat kebugaran jasmani siswa yang berada di pondok pesantren Ta'dib Asyakirin tahun 2019 untuk masingmasing item tes dapat dilihat dalam tabel sebagai berikut:

Tabel 4. Deskripsi Data Hasil Penilaian (Putra)

\begin{tabular}{lllll}
\hline No & \multicolumn{1}{c}{ Item Tes } & \multicolumn{1}{c}{ Maksimum } & \multicolumn{1}{c}{ Minimum } & \multicolumn{1}{c}{ Rata - Rata } \\
\hline 1 & Lari 60 meter (detik) & 6,3 & 16,7 & 7,93 \\
\hline 2 & Gantung Siku Tekuk (kali) & 12 & 5 & 7,49 \\
\hline 3 & Baring Duduk 60 dtk (pa) & 27 & 15 & 22,40 \\
\hline 4 & Loncat tegak (cm) & 45 & 22 & 32,68 \\
\hline 5 & Lari 1000 m & $4,2 ”$ & $6,45 ”$ & $6,10 ”$ \\
\hline
\end{tabular}

Tabel 5. Deskripsi Data Hasil Penilaian (Putri)

\begin{tabular}{llccc}
\hline No & \multicolumn{1}{c}{ Item Tes } & Maksimum & Minimum & Rata - Rata \\
\hline 1 & Lari 60 meter (detik) & 7,7 & 11,2 & 9,33 \\
\hline 2 & Gantung Siku Tekuk (kali) & 4 & 1 & 2,55 \\
\hline 3 & Baring Duduk 30 dtk (pa) & 23 & 6 & 12 \\
\hline 4 & Loncat tegak (cm) & 29 & 19 & 23,35 \\
\hline 5 & Lari 800 m & $4,32 ”$ & $7,2 ”$ & $6,42 ”$ \\
\hline
\end{tabular}

Penilaian terhadap tingkat kebugaran jasmani siswa berdasarkan norma kategori tes kebugaran jasmani indonesia untuk remaja usia 13 - 15 tahun. Hasil penelitian Tingkat Kebugaran Jasmani siswa yang berada di Pondok Pesantren Ta'dib Asyakirin Medan Tahun 2019 adalah sebagai berikut: Dari 77 siswa di Pondok Pesantren Ta'dib Asyakirin yang menjadi sampel dalam penelitian ini,
9 orang siswa $(11,69 \%)$ memiliki tingkat kebugaran jasmani dengan kategori "Sedang", 58 orang siswa (75,33\%) memiliki tingkat kebugaran jasmani dalam kategori "Kurang", dan 10 orang siswa $(12,99 \%)$ memiliki tingkat kebugaran jasmani dengan kategori "Kurang Sekali". Untuk lebih jelasnya dapat dilihat pada tabel dibawah ini :

Tabel 6. Data Kategori Tingkat Kebugaran Jasmani Siswa yang berada di Pondok Pesantren Ta'dib Asyakirin Medan Tahun 2019

\begin{tabular}{lllll}
\hline \multirow{2}{*}{ No } & \multicolumn{2}{l}{ Kategori Kebugaran Jasmani } & \multirow{2}{*}{ Frekuensi } & Presentase \\
\cline { 2 - 3 } & Nilai & Kategori & & \\
\hline 1 & $18-21$ & Sedang & 9 & $11,69 \%$ \\
\hline 2 & $14-17$ & Kurang & 58 & $75,32 \%$ \\
\hline 3 & $10-13$ & Kurang Sekali & 10 & $6,67 \%$ \\
\hline & Jumlah & & 18 & $100 \%$ \\
\hline
\end{tabular}

Berdasarkan hasil penelitian dan deskripsi data hasil penelitian maka peneliti melakukan pemnahasan: 1 . Lari 60 meter atau lari cepat jarak pendek bertujuan untuk mengukur kecepatan dan kategori jarak yang ditempuh untuk masing-masing pelari adalah 60 meter, 2. Pull up atau gantung angkat tubuh bertujuan untuk mengukur kekuatan otot lengan dan bahu serta penilaian yang dilakukan adalah kemampuan melakukan pull up selama 60 detik untuk putra dan 30 detik untuk putri, 3. Sit up atau baring duduk bertujuan untuk mengukur kekuatan dan ketahanan otot perut dan penilaian yang 
dilakukan adalah kemampuan untuk melakukan sit up selama 60 detik untuk putra dan 30 detik untuk putri, 4. Vertical Jump atau lompat raihan bertujuan untuk mengukur daya ledak otot tungkai dengan melakukan 3 kali lompatan setinggi mungkin dan setiap lompatan dicatat tingi raihan yang di dapat, dan 5. Lari 1000 / 800 meter atau lari cepat jarak jauh bertujuan untuk mengukur daya tahan paru-paru, jantung, pembuluh darah, dan jarak yang ditempuh adalah sejauh 1000 meter untuk putra dan 800 meter untuk putri.

Penelitian yang dilakukan pada siswasiswi yang berada di Pondok Pesantren Ta'dib Asyakirin Medan tersebut menunjukkan bahwa kebugaran jasmani siswa yang menjadi sampel berada pada kategori Kurang. Hal ini perlu diperhatikan oleh siswa-siswi agar dapat meningkatkan kebugaran jasmnai mereka.

Dari hasil tes tersebut ternyata jelas adanya pengaruh besar dari pendidikan jasmani terhadap tingkat kebugaran jasmani siswa. Sebaiknya setiap pesantren atau sekolah lainnya memang wajib memiliki mata pelajaran pendidikan jasmani, dengan begitu siswa-siswi yang berada di pesantren atau sekolah tersebut akan mempunyai wadah dalam mengembangkan keterampilan gerak mereka.

Nurul, Sabaruddin Yunis, Kebugaran merupakan kebugaran fisik, yakni kemampuan seseorang untuk dapat melakukan kerja seharihari secara efisien tanpa timbul kelelahan yang berlebihan sehingga masih dapat menikmati waktu luangnya. Manfaat yang diperoleh jika memiliki kebugaran jasmani yang baik adalah memberikan kemudahan bagi seseorang atau siswa dalam melaksanakaan tugas sehari-hari tanpa mengalami kelelahan yang berarti dan akan menghindari seseorang dari berbagai macam penyakit baik ringan maupun berat serta meningkatkan kemampuan belajar.

Hanya sedikit siswa yang memiliki kebugaran jasmani yang cukup, tetapi jumlahnya tidak lebih banyak dari siswa yang lebih banyak memiliki tingkat kebugaran jasmani yang kurang, bahkan ada beberapa siswa juga yang memiliki tingkat kebugaran jasmani kurang sekali. Nurul, Sabaruddin Yunis (2019) tingkat kebugaran antara satu siswa dengan siswa lainnya berbeda-beda.
Siswa yang memiliki kebugaran jasmani yang baik cenderung terlihat aktif di dalam kelas dan memiliki prestasi yang baik di cabang olahraga. Sedangkan siswa yang memiliki kebugaran jasmani yang kurang akan terlihat lesu dan kurang bersemangat dalam belajar. Hal tersebut diduga disebabkan oleh faktor-faktor yang dipengaruhi oleh berikut ini:

1. Faktor umur sangat dominan terkait komponen kebugaran, berdasarkan hasil penelitian dan temuan dilapangan, faktor umur tidak ditemukan, semua pelajar yang sekolah di pesantren Ta'dib Asyakirin Medan memiliki usia yang cukup atau tepat waktu.

2. Jenis kelamin, kebugaran antara siswa putra dan putri di pondok pesantren Ta'dib Asyakirin berbeda karena adanya perbedaan ukuran tubuh yan terjadi setelah pubertas. Rata-rata wanita memiliki kebugaran lebih kecil dari pada pria.

3. Genetik, genetik berpengaruh pada tubuh seseorang sejak lahir. Pengaruh genetik pada kekuatan otot dan daya tahan otot pada umumnya berhubungan dengan komposisi serabut otot yang terdiri dari serat merah dan serat putih. Seseorang yang memiliki serat merah lebih tepat untuk melakukan kegiatan aerobic dan begitu pula sebaliknya.

4. Faktor kebiasaan latihan yang rendah menjadi penyebab utama para pelajar belum memiliki kebugaran jasmani yang cukup baik, selanjutnya Kurangnya sarana dan prasarana di pesantren, sarana dan prasarana di pesantren tidak mencukupi untuk melakukan kegiatan belajar mengajar olahraga di pesantren.

5. Kegiatan fisik, tidak adanya wadah bagi siswa untuk melakukan kegiatan fisik yaitu semacam ekstrakurikuler yan berhubungan dengan olahraga. Sehinga menyebabkan kurangnya kebugaran jasmani siswa di pesantren. Materi pendidikan siswa yang monoton, materi yang disajikan guru terbatas diakibatkan oleh tidak adanya sarana dan prasarana di pesantren.

6. Kondisi kesehatan para pelajar pesantren Ta'dib Asyakirin Medan secara umum baik, hanya saja tingkat kebugaran jasmani yang rendah, penyebabnya kurangnya aktivitas fisik dan berolahraga. Selanjutnya tidak adanya ekstrakurikuler di pesantren menjadikan keterampilan 
pelajar tidak tersalurkan, sehingga siswa tidak bisa menjaga kebugaran dan meningkatkan prestasi olahraga di pesantren. Adanya siswa yang memiliki penyakit atau kelainan yang dapat menyebabkan berkurangnya kegiatan olahraga, sehingga siswa tersebut memiliki kebugaran yang rendah.

7. Pola hidup sehat para pelajar pesantren Ta'dib Asyakirin Medan secara umum belum baik, waktu istirahat sangat terbatas karena harus mengikuti aktivitas kurikulum sekolah dan aktivitas keagamaan sehingga untuk aktivitas olahraga sangat sedikit sekali.

8. Berdasarkan hasil penelitian jadwal istirahat para pelajar pesantren Ta'dib Asyakirin Medan sangat terbatas, rutinitas para pelajar dominan kearah keagamaan.

9. Secara umum faktor gizi pelajar pesantren Ta'dib Asyakirin Medan sangat terbatas, jika dikaitkan menunjang aktivitas fisik pelajar di pesantren Ta'dib Asyakirin Medan memang belum memadai.

10. Karena keterbatasan penelitian ini, maka kadar haemoglobin para pelajar pesantren Ta'dib Asyakirin Medan belum dilaksanakan.

Kebugaran merupakan faktor penentu dalam segala aspek kehidupan. Siswa yang memiliki tingkat jasmani yang kurang akan mempengaruhi kondisi tubuhnya dan tidak dapat melakukan aktvitas pembelajaran di pesantren. Siswa yang memiliki kebugaran jasmani yang kurang umumnya akan menurun prestasinya. Hal ini disebabkan kondisi kebugaran jasmani yang tidak prima sehingga kemampuan berpikirpun terganggu. Secara psikologis, anak yan memiliki kebugaran jasmani kurang akan menunjukkan sikap yang kurang agresif dan minat belajar rendah.

\section{KESIMPULAN \& SARAN}

Data hasil penelitian tingkat kebugaran yang diperoleh dengan menggunakan Tes kebugaran Jasmani Indonesia yang di ikuti oleh 77 orang siswa yang berada di Pondok Pesantren Ta'dib Asyakirin Medan menunjukkan bahwa siswa yang tingkat kebugarannya pada kategori sedang yaitu sejumlah 9 orang, 58 siswa berada di kategori kurang, 10 siswa berada di kategori kurang sekali, dan tidak ada satupun siswa yang berada dalam kategori baik. Kesimpulan penelitian ini adalah dari tingkat kebugaran jasmani siswa yang berada di Pondok
Pesantren Ta'dib Asyakirin Medan yakni berada pada kategori kurang

\section{DAFTAR PUSTAKA}

Arikunto, Suharsimi. 2006. Prosedur Penelitian: Suatu Pendekatan Praktik, Edisi Revisi VI. Jakarta: PT Rineka Cipta.

Arikunto, S. 2006. Metode Penelitian Kualitatif. Jakarta: Bumi Aksara.

Djoko Pekik Irianto. 2004. Pedoman Praktis Berolahraga. Yogyakarta: Andi Offset.

Harsono. 2006. Latihan Kondisi Fisik. Jakarta: Bina Aksara.

Kemendiknas. 2010. Tes Kesegaran Jasmani Indonesia untuk Anak Umur 13 - 15 Tahun. Jakarta: Kemendiknas.

Kravitz Len. 2001. Panduan Lengkap Bugar Total. Divisi Buku Sport. Jakarta: PT. Raja grafindo Persaja.

Lutan, Rusli. 2002. Menuju Sehat dan Bugar. Jakarta: Direktorat Jendral Olahraga, Depdiknas.

Mukholid, Agus. 2007. Pendidikan Jasmani Olahraga dan Kesehatan. Surakarta: Yudistira.

Nurul Winda, Sabaruddin Yunis Bangun. 2019. Tingkat Kebugaran Jasmani Siswa SMP Negeri se-Kecamatan Bosar Maligas Kabupaten Simalungun Provinsi Sumatera Utara. Journal of Sport Science and Education. Volume: 4, Edisi: 1: 31-35.

Sabaruddin Yunis Bangun. 2012. Analisis Tujuan Materi Pelajaran dan Metode Pembelajaran Dalam Pendidikan Jasmani. Jurnal Cerdas Sifa. Volume: 1, Edisi: 1: 1-10.

Sabaruddin Yunis Bangun. 2016. Peran Pendidikan Jasmani Dan Olahraga Pada Lembaga Pendidikandi Indonesia. Publikasi Pendidikan: Jurnal Pemikiran, Penelitian dan Pengabdian Masyarakat Bidang Pendidikan. Volume: 6, Edisi: 3: 156167.

Sugiyono. 2012. Metode Penelitian Pendidikan Pendekatan Kuantitatif, Kualitatif, dan $R \& D$. Bandung: Alfa Beta.

Toho Cholik Mutahir \& Ali Maksum. 2007. Sport Developmen Index. Jakarta: PT Indeks. 